\title{
Management Urethral Trauma
}

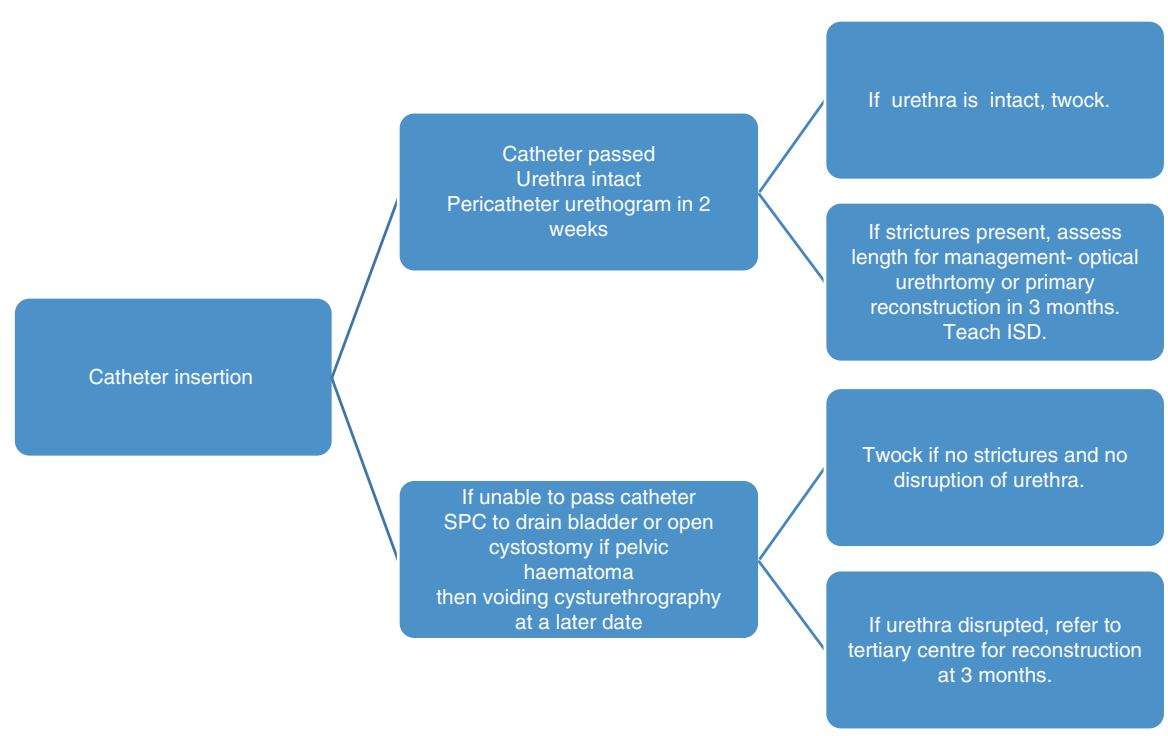

\section{Suggested Reading}

McGeady JB, Breyer BN. Current epidemiology of genitourinary trauma. Urol Clin North Am. 2013;40(3):323-33.

Morey AF, Steve B, Dugi DD III, Armstrong JH, Breyer BN, Broghammer JA, Erickson BA, Holzbeierlein J, Hudak SJ, Mirvis S, Pruitt JH, Reston JT, Santucci RA, Smith TG III, Wessells H. Urotrauma: AUA guideline. J Urol. 2014;192(2):327-35.

Zaid UB, Bayne DB, Harris CR, Alwaal A, McAninch JW, Breyer BN. Penetrating trauma to the ureter, bladder, and urethra. Curr Trauma Rep. 2015;1(2):119-24. 